\title{
Triggering of Suicidal Erythrocyte Death by Topotecan
}

\author{
Rosi Bissinger ${ }^{\mathrm{a}}$ Ghada Bouguerra $^{\mathrm{b}} \quad$ Katja Stockinger $^{\mathrm{a}} \quad$ Salem Abbès ${ }^{\mathrm{b}} \quad$ Florian Lang $^{\mathrm{a}}$ \\ aDepartment of Physiology, University of Tuebingen, Tuebingen, Germany; 'baboratoire d'Hématologie \\ Moléculaire et Cellulaire, Institut Pasteur de Tunis, Université Tunis-El Manar, Tunis, Tunisia
}

\section{Key Words}

Phosphatidylserine $\cdot$ Cell volume $\cdot$ Ceramide $\cdot$ Calcium $•$ Oxidative stress $\bullet$ Eryptosis

\begin{abstract}
Background/Aims: The topoisomerase I inhibitor topotecan is used as treatment of various malignancies. The substance is effective by triggering tumor cell apoptosis. In analogy to apoptosis of nucleated cells, erythrocytes may enter eryptosis, a suicidal death characterized by cell shrinkage and cell membrane scrambling with phosphatidylserine translocation to the outer face of the erythrocyte membrane. Signaling leading to eryptosis include $\mathrm{Ca}^{2+}$ entry and ceramide formation. The present study explored, whether and how topotecan induces eryptosis. Methods: Phosphatidylserine abundance at the erythrocyte surface was estimated from annexin $\mathrm{V}$ binding, cell volume from forward scatter, and ceramide abundance utilizing specific antibodies. Results: A 48 hours exposure of human erythrocytes to topotecan significantly increased the percentage of annexin- $\mathrm{V}$-binding cells and significantly decreased forward scatter. The effect of topotecan was paralleled by a significant increase of ceramide abundance. The effect of topotecan on annexin-V-binding was significantly blunted, but not abolished by removal of extracellular $\mathrm{Ca}^{2+}$. Conclusions: Topotecan stimulated cell shrinkage and phospholipid scrambling of the erythrocyte cell membrane, an effect paralleled by increase of ceramide abundance and partially dependent on entry of extracellular $\mathrm{Ca}^{2+}$.
\end{abstract}

Copyright $(2015$ S. Karger AG, Basel

\section{Introduction}

The camptothecin analogue [1] topotecan is utilized for the treatment of malignancy, such as ovarian cancer [2-7], cervical cancer [5, 8-10], retinoblastoma [11-13], small cell lung cancer [14-18], hematopoietic cell malignancy [19, 20] and Wilms' tumor [21]. It is applied at a dosage of $10 \mathrm{mg} / \mathrm{kg} \mathrm{b.w.} \mathrm{in} \mathrm{mice} \mathrm{and} \mathrm{reaches} \mathrm{plasma} \mathrm{concentrations} \mathrm{of} \mathrm{up} \mathrm{to} 180$ $\mu \mathrm{g} / \mathrm{mL}$ [22]. In humans, the maximally tolerated topotecan dose is $0.75 \mathrm{mg} / \mathrm{m}^{2}$ which results

Prof. Dr. Florian Lang

KARGER 125
Department of Physiology, University of Tuebingen,

Gmelinstr. 5, 72076 Tuebingen, (Germany)

Tel. +4970712972194, Fax +497071295618, E-Mail florian.lang@uni-tuebingen.de 
in a mean peak plasma concentration of $2.74 \mathrm{ng} / \mathrm{mL}$ [23]. Side effects of topotecan include thrombocytopenia, neutropenia, alopecia, fatigue, diarrhea, nausea and anemia [24].

Topotecan is effective against tumor cells in part by triggering apoptosis [1,25-33]. The cytotoxicity of topotecan has been attributed to inhibition of topoisomerase I [1, 33-37], double-stranded DNA damage $[8,33]$, down-regulation of the transcription factors MycN [38], NF- $\kappa B$ [30] and HIF-1 $\alpha$ [36], suppression of PTEN [32], VEGF [36] and Bcl-2 expression $[31,37]$, oxidative stress [25], decrease of Akt activity [36], as well as caspase activation $[25-27,33,37]$.

In analogy to apoptosis of nucleated cells, erythrocytes may enter eryptosis, the suicidal death of erythrocytes characterized by cell shrinkage [39] and break down of phospholipid asymmetry of the cell membrane leading to phosphatidylserine translocation to the cell surface [40]. Signaling triggering eryptosis include $\mathrm{Ca}^{2+}$ entry with increase of cytosolic $\mathrm{Ca}^{2+}$ activity $\left(\left[\mathrm{Ca}^{2+}\right]_{\mathrm{i}}\right)[40]$, ceramide [41], energy depletion [40], oxidative stress [40], caspase activation $[40,42,43]$, stimulation of casein kinase $1 \alpha[44,45]$, Janus-activated kinase JAK3 [46], protein kinase C [47] and p38 kinase [48]. Eryptosis is inhibited by PAK2 kinase [49], AMP activated kinase AMPK [50], cGMP-dependent protein kinase [51] and sorafenib/ sunitinib sensitive kinases $[52,53]$. Eryptosis is triggered by a myriad of xenobiotics $[40$, 54-84].

The present study explored, whether and how topotecan triggers eryptosis. To this end, human erythrocytes from healthy volunteers were exposed to Ringer without or with topotecan and cell volume as well as phosphatidylserine and ceramide abundance determined by flow cytometry.

\section{Materials and Methods}

Erythrocytes, solutions and chemicals

Fresh Li-Heparin-anticoagulated blood samples were kindly provided by the blood bank of the University of Tübingen. The study is approved by the ethics committee of the University of Tübingen $(184 / 2003 \mathrm{~V})$. The blood was centrifuged at $120 \mathrm{xg}$ for $20 \mathrm{~min}$ at $21^{\circ} \mathrm{C}$ and the platelets and leukocytescontaining supernatant was disposed. Erythrocytes were incubated in vitro at a hematocrit of $0.4 \%$ in Ringer solution containing (in mM) $125 \mathrm{NaCl}, 5 \mathrm{KCl}, 1 \mathrm{MgSO}_{4}, 32 \mathrm{~N}$-2-hydroxyethylpiperazine-N-2-ethanesulfonic acid (HEPES, pH 7.4), 5 glucose, and $1 \mathrm{CaCl}_{2}$; at $37^{\circ} \mathrm{C}$ for 48 hours. Where indicated, erythrocytes were exposed to topotecan (Tocris Cookson Ltd., Bristol, UK) at the indicated concentrations.

\section{Annexin-V-binding and forward scatter}

After incubation under the respective experimental condition, a $150 \mu \mathrm{l}$ cell suspension was washed in Ringer solution containing $5 \mathrm{mM} \mathrm{CaCl}_{2}$ and then stained with Annexin-V-FITC (1:200 dilution; ImmunoTools, Friesoythe, Germany) in this solution at $37^{\circ} \mathrm{C}$ for 20 min under protection from light. The annexin $\mathrm{V}$ abundance at the erythrocyte surface was subsequently determined on a FACS Calibur (BD, Heidelberg, Germany). Annexin V binding was measured with an excitation wavelength of $488 \mathrm{~nm}$ and an emission wavelength of $530 \mathrm{~nm}$. A marker (M1) was placed to set an arbitrary threshold between annexin V-binding cells and control cells. The same threshold was used for untreated and topotecan treated erythrocytes. A dot plot of forward scatter (FSC) vs. side scatter (SSC) was set to linear scale for both parameters. The threshold of forward scatter was set at the default value of " 52 ", i.e. values below 52 were not considered.

Intracellular $\mathrm{Ca}^{2+}$

After incubation, erythrocytes were washed in Ringer solution and then loaded with Fluo-3/AM (Biotium, Hayward, USA) in Ringer solution containing $5 \mathrm{mM} \mathrm{CaCl}_{2}$ and $5 \mu \mathrm{M}$ Fluo-3/AM. The cells were incubated at $37^{\circ} \mathrm{C}$ for $30 \mathrm{~min}$ and washed twice in Ringer solution containing $5 \mathrm{mM} \mathrm{CaCl}$. The Fluo-3/ AM-loaded erythrocytes were resuspended in $200 \mu \mathrm{l}$ Ringer. Then, $\mathrm{Ca}^{2+}$-dependent fluorescence intensity was measured with an excitation wavelength of $488 \mathrm{~nm}$ and an emission wavelength of $530 \mathrm{~nm}$ on a FACS Calibur. No lower threshold of Fluo3 fluoresence was set. 
Ceramide abundance

For the determination of ceramide, a monoclonal antibody-based assay was used. After incubation, a $100 \mu \mathrm{l}$ cell suspension was stained for 1 hour at $37^{\circ} \mathrm{C}$ with $1 \mu \mathrm{g} / \mathrm{mL}$ anti-ceramide antibody (clone MID 15B4, Alexis, Grünberg, Germany) in PBS containing $0.1 \%$ bovine serum albumin (BSA) at a dilution of 1:10. The samples were washed twice with PBS-BSA. Subsequently, the cells were stained for 30 minutes with polyclonal fluorescein isothiocyanate (FITC) conjugated goat anti-mouse IgG and IgM specific antibody (Pharmingen, Hamburg, Germany) diluted 1:50 in PBS-BSA. Unbound secondary antibody was removed by repeated washing with PBS-BSA. The samples were then analyzed by flow cytometric analysis with an excitation wavelength of $488 \mathrm{~nm}$ and an emission wavelength of $530 \mathrm{~nm}$.

Reactive oxygen species (ROS)

Oxidative stress was determined utilizing 2', 7'-dichlorodihydrofluorescein diacetate (DCFDA). After incubation, a $150 \mu \mathrm{l}$ suspension of erythrocytes was washed in Ringer solution and then stained with DCFDA (Sigma, Schnelldorf, Germany) in Ringer solution containing DCFDA at a final concentration of 10 $\mu \mathrm{M}$. Erythrocytes were incubated at $37^{\circ} \mathrm{C}$ for $30 \mathrm{~min}$ in the dark and then washed three times in Ringer solution. The DCFDA-loaded erythrocytes were resuspended in $200 \mu$ l Ringer solution, and ROS-dependent fluorescence intensity was measured at an excitation wavelength of $488 \mathrm{~nm}$ and an emission wavelength of $530 \mathrm{~nm}$ on a FACS Calibur (BD).

\section{Statistics}

Data are expressed as arithmetic means \pm SEM. As indicated in the figure legends, statistical analysis was made using ANOVA with Tukey's test as post-test and $t$ test as appropriate; $n$ denotes the number of different erythrocyte specimens studied. Since different erythrocyte specimens used in distinct experiments are differently susceptible to triggers of eryptosis, the same erythrocyte specimens have been used for control and experimental conditions.

\section{Results}

The present study tested, whether topotecan modifies suicidal erythrocyte death or eryptosis. To this end, the hallmarks of eryptosis, i.e. cell shrinkage and cell membrane scrambling with phosphatidylserine translocation to the cell surface, were determined utilizing flow cytometry.

Cell volume was estimated from forward scatter. As illustrated in Fig. 1, exposure of erythrocytes for 48 hours to Ringer solution with $125-175 \mu \mathrm{g} / \mathrm{mL}$ topotecan was followed by a marked significant decrease of forward scatter reflecting cell shrinkage.

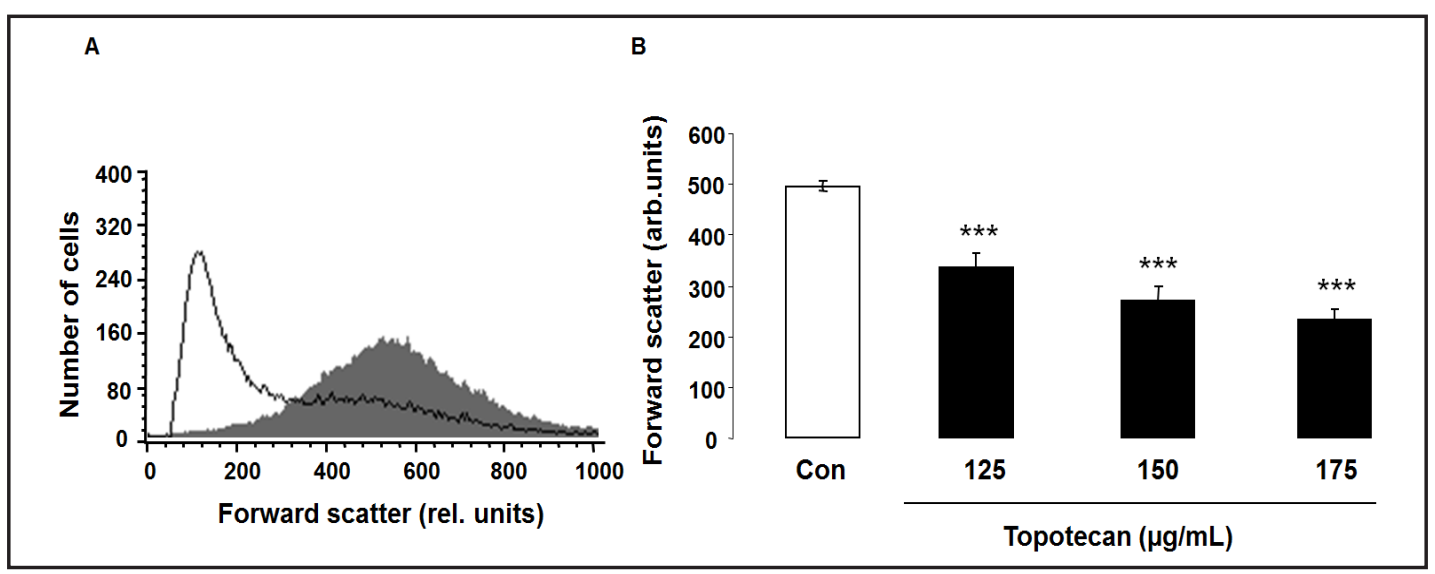

Fig. 1. Effect of topotecan on erythrocyte forward scatter. (A) Original histogram of forward scatter of erythrocytes following exposure for 48 hours to Ringer solution without (grey area) and with (black line) presence of $175 \mu \mathrm{g} / \mathrm{mL}$ topotecan. (B) Arithmetic means \pm SEM $(\mathrm{n}=8)$ of the erythrocyte forward scatter (FSC) following incubation for 48 hours to Ringer solution without (white bar) or with (black bars) topotecan $(125-175 \mu \mathrm{g} / \mathrm{mL}){ }^{* * *}(\mathrm{P}<0.001)$ indicates significant difference from the absence of topotecan (ANOVA). 


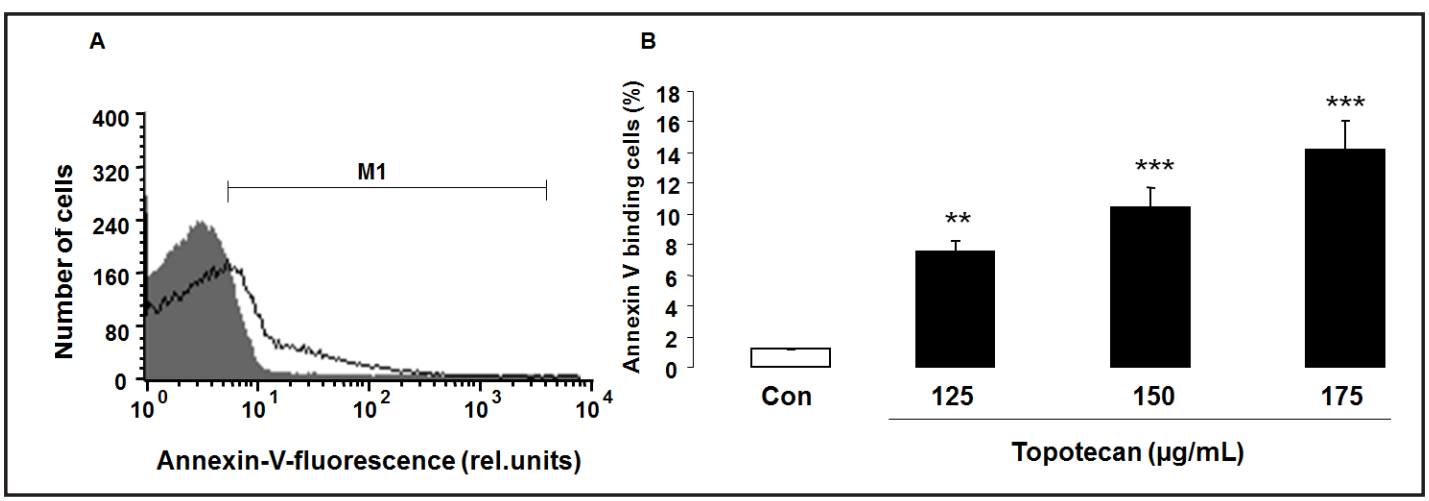

Fig. 2. Effect of topotecan on phosphatidylserine exposure. (A) Original histogram of annexin-V-binding of erythrocytes following exposure for 48 hours to Ringer solution without (grey area) and with (black line) presence of $175 \mu \mathrm{g} / \mathrm{mL}$ topotecan. (B) Arithmetic means \pm SEM ( $=8$ ) of erythrocyte annexin-V-binding following incubation for 48 hours to Ringer solution without (white bar) or with (black bars) topotecan $(125-175 \mu \mathrm{g} / \mathrm{mL}){ }^{* *}(\mathrm{P}<0.01),{ }^{* * *}(\mathrm{P}<0.001)$ indicate significant difference from the absence of topotecan (ANOVA).

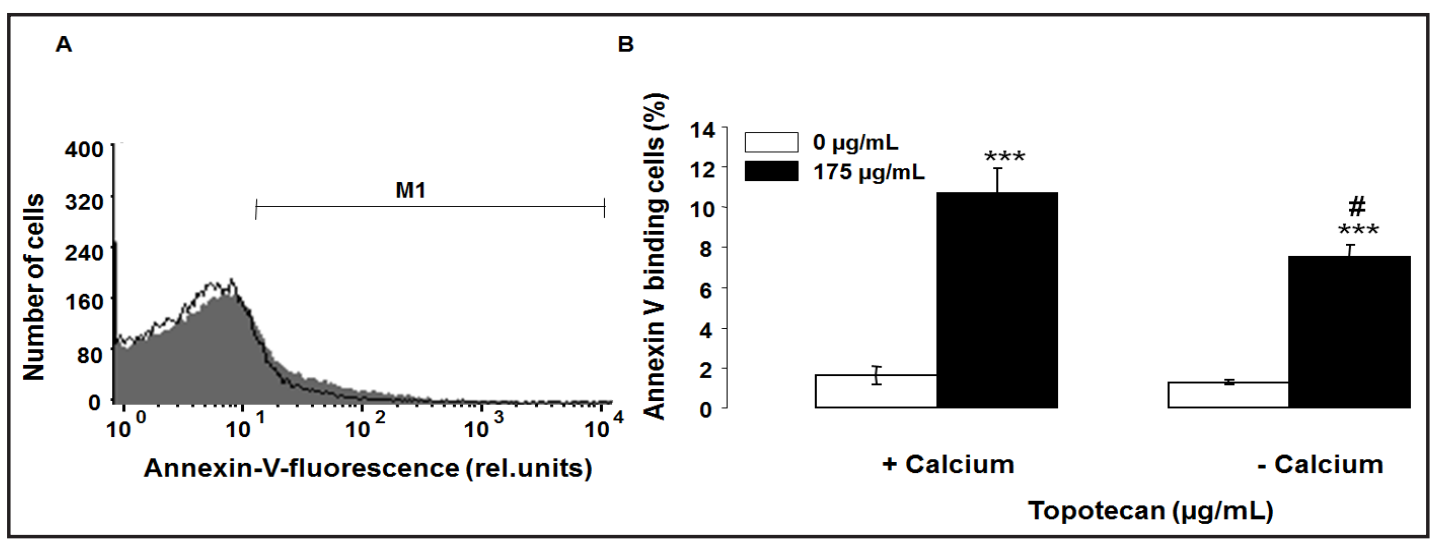

Fig. 3. $\mathrm{Ca}^{2+}$ sensitivity of topotecan induced translocation of phosphatidylserine exposure. (A) Original histogram of annexin-V-binding of erythrocytes following exposure for 48 hours to Ringer solution in the absence of extracellular $\mathrm{Ca}^{2+}$ without (grey area) and with (black line) presence of $175 \mu \mathrm{g} / \mathrm{mL}$ topotecan. (B) Arithmetic means \pm SEM $(n=10)$ of annexin-V-binding of erythrocytes after a 48 hours treatment with Ringer solution without (white bars) or with $175 \mu \mathrm{g} / \mathrm{mL}$ topotecan (black bars) in the presence (left bars, $\left.+\mathrm{Ca}^{2+}\right)$ and absence (right bars, $\left.-\mathrm{Ca}^{2+}\right)$ of $\mathrm{Ca}^{2+}$. ${ }^{* *}(\mathrm{P}<0.001)$ indicates significant difference from the absence of topotecan, \# $(\mathrm{P}<0.05)$ indicates significant difference from the presence of $\mathrm{Ca}^{2+}(\mathrm{ANOVA})$.

Phosphatidylserine at the erythrocyte surface was quantified utilizing annexin-Vbinding. As shown in Fig. 2, exposure of erythrocytes for 48 hours to Ringer solution with $125-175 \mu \mathrm{g} / \mathrm{mL}$ topotecan was followed by a marked significant increase of the percentage of annexin-V-binding erythrocytes reflecting an increase of phosphatidylserine exposing erythrocytes.

Further experiments were performed in order to shed light on the signaling mediating topotecan induced eryptosis. Attempts were made to determine cytosolic $\mathrm{Ca}^{2+}$ activity $\left(\left[\mathrm{Ca}^{2+}\right]_{\mathrm{i}}\right)$ with Fluo3 fluorescence. However, topotecan treatment was followed by a decrease of Fluo3 fluorescence in the presence of $\mathrm{Ca}^{2+}$ ionophore ionomycin $(1 \mu \mathrm{M} 60 \mathrm{~min})$ pointing to loss of fluorescent dye. Possibly, topotecan inhibits the cytosolic esterases or permeabilizes the cell membrane for the dye. Alternatively the average was decreased by Fluo3 containing vesicles. In any case, the effect precluded safe conclusions regarding the effect of topotecan on $\left[\mathrm{Ca}^{2+}\right]_{\mathrm{i}}$.

\section{KARGER}




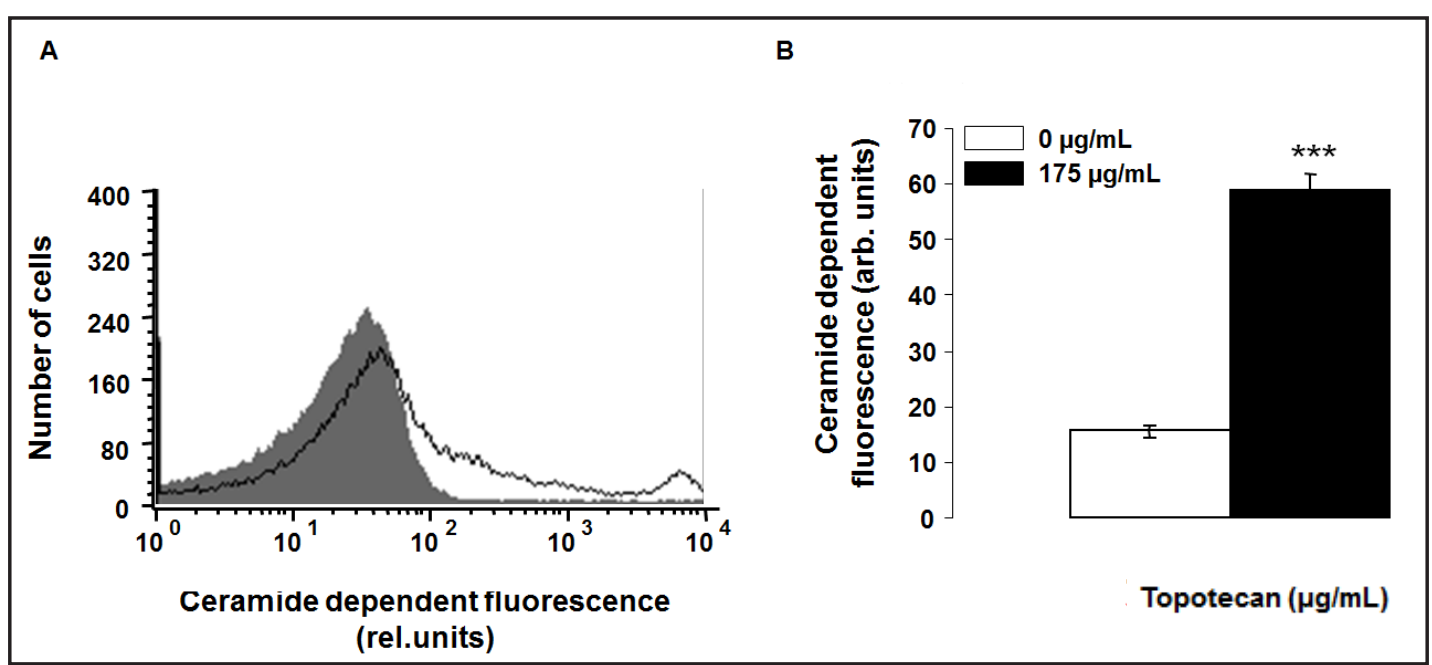

Fig. 4. Effect of topotecan on ceramide abundance. (A) Original histogram of ceramide abundance at the erythrocyte surface following exposure for 48 hours to Ringer solution without (grey area) and with (black line) presence of $175 \mu \mathrm{g} / \mathrm{mL}$ topotecan. (B) Arithmetic means \pm SEM ( $\mathrm{n}=5)$ of ceramide abundance at the erythrocyte surface following incubation for 48 hours to Ringer solution without (white bar) or with 175 $\mu \mathrm{g} / \mathrm{mL}$ topotecan (black bar). ${ }^{* * *}(\mathrm{P}<0.001)$ indicates significant difference from the absence of topotecan ( $\mathrm{t}$ test).

In order to test whether the effect of topotecan on cell volume and/or phosphatidylserine translocation required entry of extracellular $\mathrm{Ca}^{2+}$, forward scatter and annexin-V-binding were determined following exposure to topotecan $(175 \mu \mathrm{g} / \mathrm{mL})$ in the presence and in the absence of extracellular $\mathrm{Ca}^{2+}$. As a result, topotecan exposure was followed by a significant decrease of forward scatter to similar values in the presence and in the absence of extracellular $\mathrm{Ca}^{2+}$. In the presence of $\mathrm{Ca}^{2+}$, topotecan decreased the forward scatter from $505 \pm 7$ to $266 \pm 26 \mathrm{n}=10$ ) and in the absence of $\mathrm{Ca}^{2+}$, topotecan decreased the forward scatter from $506 \pm 8$ to $254 \pm 24(n=10)$. No significant differences were observed between presence and absence of $\mathrm{Ca}^{2+}$. Accordingly, entry of $\mathrm{Ca}^{2+}$ did not account for the stimulation of cell shrinkage following topotecan exposure. As illustrated in Fig. 3, topotecan exposure was followed by a significant increase of the percentage of annexin-V-binding erythrocytes both, in the presence and in the absence of extracellular $\mathrm{Ca}^{2+}$. The effect was, however, significantly blunted in the absence of extracellular $\mathrm{Ca}^{2+}$. Accordingly, topotecan-induced cell membrane scrambling was partially but not fully dependent on entry of $\mathrm{Ca}^{2+}$.

Stimulators of eryptosis without requirement of increased $\left[\mathrm{Ca}^{2+}\right]_{\mathrm{i}}$ include ceramide. In order to test, whether topotecan influences ceramide abundance at the erythrocyte surface, ceramide was visualized with specific antibodies. As a result, a 48 hours incubation with topotecan $(175 \mu \mathrm{g} / \mathrm{mL})$ significantly increased the ceramide abundance (Fig. 4).

Triggers of eryptosis further include oxidative stress. Reactive oxygen species (ROS) was thus quantified utilizing $2^{\prime}, 7^{\prime}$-dichlorodihydrofluorescein diacetate (DCFDA). As a result, following a 48 hours incubation the DCFDA fluorescence was rather lower in the presence $(12.2 \pm 0.9$ a.u., $\mathrm{n}=5)$ than in the absence $(16.9 \pm 2.4$ a.u., $\mathrm{n}=5)$ of topotecan $(175 \mu \mathrm{g} /$ $\mathrm{mL}$ ), a difference, however, not reaching statistical significance. For comparison, a 10 mins exposure of erythrocytes to $0.3 \mathrm{mM}$ tert-butylhydroperoxide (TBOOH) was followed by a significant increase of DCFDA fluorescence (182.6 \pm 10.8 a.u., $\mathrm{n}=4)$.

Eryptosis is further stimulated by caspases. In order to test whether the effect of topotecan on phosphatidylserine translocation required caspase activity, annexin-V-binding was determined following exposure to topotecan $(175 \mu \mathrm{g} / \mathrm{mL})$ in the presence and in the absence of caspase inhibitor zVAD $(10 \mu \mathrm{M})$. As a result, topotecan exposure was followed by a significant increase of annexin-V-binding to similar values in the absence and presence of zVAD. Topotecan increased the percentage of annexin-V-binding erythrocytes from $3.0 \pm$ 
0.4 to $17.0 \pm 0.6(n=5)$ in the absence of zVAD and from $3.6 \pm 0.4$ to $16.5 \pm 0.6(n=5)$ in the presence of zVAD. No significant differences were observed between presence and absence of zVAD.

\section{Discussion}

The present observations uncover a novel action of topotecan, i.e. the stimulation of eryptosis, the suicidal erythrocyte death. Eryptosis is characterized by the two hallmarks cell shrinkage and cell membrane scrambling with phosphatidylserine translocation to the erythrocyte surface. Topotecan exposure was followed by both, decrease of forward scatter reflecting cell shrinkage and by increase of annexin-V-binding, reflecting phosphatidylserine abundance at the cell surface. The concentrations required are in the range of those reported in plasma of mice treated with liposome-encapsulated topotecan [22]. Concentrations effective in the treatment of tumors, are however, lower, i.e. in the range of $2.7 \mathrm{ng} / \mathrm{mL}$ to $0.21 \mu \mathrm{g} / \mathrm{mL}[23$, 85]. It must be kept in mind, though, that the susceptibility to triggers of eryptosis is enhanced in several clinical conditions, such as dehydration [70], hyperphosphatemia [81], chronic kidney disease (CKD) [59, 86-88], hemolytic-uremic syndrome [89], diabetes [90], liver failure [91], malignancy [92], sepsis [93] and Wilsons disease [94].

Topotecan triggered cell membrane scrambling was in part dependent on presence of extracellular $\mathrm{Ca}^{2+}$ and presumably required in part $\mathrm{Ca}^{2+}$ entry. An increase of $\left[\mathrm{Ca}^{2+}\right]_{\mathrm{i}}$ stimulates cell membrane scrambling [40] and activates $\mathrm{Ca}^{2+}$ sensitive $\mathrm{K}^{+}$channels with subsequent cell shrinkage due to $\mathrm{K}^{+}$exit, cell membrane hyperpolarization, and $\mathrm{Cl}^{-}$exit, which lead to cellular loss of $\mathrm{KCl}$ with osmotically obliged water [39]. Removal of extracellular $\mathrm{Ca}^{2+}$ did, however, not significantly modify topotecan-induced cell shrinkage and only partially blunted cell membrane scrambling pointing to involvement of additional cellular mechanisms.

The stimulation of cell membrane scrambling was paralleled by increase of ceramide abundance at the cell surface. Ceramide is a well known trigger of eryptosis even in the absence of increased $\left[\mathrm{Ca}^{2+}\right]_{\mathrm{i}}[40]$.

The stimulation of cell membrane scrambling was not paralleled by increase of reactive oxidant species (ROS), which is another well known trigger of eryptosis [40].

Eryptosis accomplishes the clearance of defective erythrocytes prior to hemolysis [40], thus preventing release of hemoglobin, which is filtered in renal glomeruli, precipitates in the acidic lumen of renal tubules and thus occludes nephrons [95]. Eryptosis further leads to clearance of infected erythrocytes in malaria, and may thus favourably influence the clinical course of the disease [96]. The malaria pathogen Plasmodium imposes oxidative stress on the infected host erythrocyte with subsequent activation of host cell ion channels including $\mathrm{Ca}^{2+}$-permeable erythrocyte cation channels $[40,97]$. The $\mathrm{Ca}^{2+}$-entry triggers eryptosis with subsequent clearance of the infected erythrocytes [96]. Enhanced susceptibility to eryptosis thus protects against a severe course of the disease. Accordingly, sickle-cell trait, betathalassemia-trait, $\mathrm{Hb}-\mathrm{C}$ and G6PD-deficiency protect against a severe course of malaria [40, 98-100]. Eryptosis is further triggered and thus the course of malaria favourably influenced by iron deficiency [101] and treatment with lead [101], chlorpromazine [102] or NO synthase inhibitors [102].

The clearance of phosphatidylserine exposing erythrocytes from circulating blood following eryptosis may lead to anemia [40]. Moreover, phosphatidylserine exposing erythrocytes adhere to the vascular wall [103], trigger blood clotting and elicit thrombosis [104-106]. Stimulation of eryptosis may thus lead to impairment of microcirculation [41, 104, 107-110].

\section{Conclusion}

Topotecan triggers eryptosis with cell shrinkage and cell membrane scrambling, an effect involving $\mathrm{Ca}^{2+}$ entry and increase of ceramide abundance. 


\section{Cellular Physiology Cell Physiol Biochem 2015;37:1607-1618 \begin{tabular}{l|l} 
and Biochemistry Published online: November 05, 2015 & $\begin{array}{l}\text { C 2015 S. Karger AG, Basel } \\
\text { www.karger.com/cpb }\end{array}$ \\
\hline
\end{tabular} \\ Bissinger et al.: Topotecan-Induced Eryptosis}

\section{Acknowledgements}

The authors acknowledge the meticulous preparation of the manuscript by Tanja Loch and Lejla Subasic. The study was supported by the Deutsche Forschungsgemeinschaft and Open Access Publishing Fund of Tuebingen University.

\section{Disclosure Statement}

The authors declare that they have nothing to disclose.

\section{References}

1 Trojandt S, Knies D, Pektor S, Ritz S, Mailander V, Grabbe S, Reske-Kunz AB, Bros M: The chemotherapeutic agent topotecan differentially modulates the phenotype and function of dendritic cells. Cancer Immunol Immunother 2013;62:1315-1326.

2 Bryant CS, Kumar S, Spannuth W, Shah JP, Munkarah AR, Deppe G, Alvarez RD, Morris RT: Feasibility of extension of platinum-free interval with weekly bolus topotecan and subsequent platinum retreatment outcomes in recurrent ovarian cancer. Arch Gynecol Obstet 2011;283:361-367.

3 Cormio G, Loizzi V, Gissi F, Camporeale A, De Mitri P, Leone L, Putignano G, Selvaggi L: Long-term topotecan therapy in recurrent or persistent ovarian cancer. Eur J Gynaecol Oncol 2011;32:153-155.

4 Edwards SJ, Barton S, Thurgar E, Trevor N: Topotecan, pegylated liposomal doxorubicin hydrochloride, paclitaxel, trabectedin and gemcitabine for advanced recurrent or refractory ovarian cancer: a systematic review and economic evaluation. Health Technol Assess 2015;19:1-480.

5 Lorusso D, Pietragalla A, Mainenti S, Masciullo V, Di Vagno G, Scambia G: Review role of topotecan in gynaecological cancers: current indications and perspectives. Crit Rev Oncol Hematol 2010;74:163-174.

6 Peng LH, Chen XY, Wu TX: Topotecan for ovarian cancer. Cochrane Database Syst Rev 2008;10.1002/14651858.CD005589.pub2CD005589.

7 Sehouli J, Oskay-Ozcelik G: Current role and future aspects of topotecan in relapsed ovarian cancer. Curr Med Res Opin 2009;25:639-651.

8 Musa F, Blank S, Muggia F: A pharmacokinetic evaluation of topotecan as a cervical cancer therapy. Expert Opin Drug Metab Toxicol 2013;9:215-224.

9 Paton F, Paulden M, Saramago P, Manca A, Misso K, Palmer S, Eastwood A: Topotecan for the treatment of recurrent and stage IVB carcinoma of the cervix. Health Technol Assess 2010;14 Suppl 1:55-62.

10 Robati M, Holtz D, Dunton CJ: A review of topotecan in combination chemotherapy for advanced cervical cancer. Ther Clin Risk Manag 2008;4:213-218.

11 Mallipatna AC, Dimaras H, Chan HS, Heon E, Gallie BL: Periocular topotecan for intraocular retinoblastoma. Arch Ophthalmol 2011;129:738-745.

12 Marr BP, Brodie SE, Dunkel IJ, Gobin YP, Abramson DH: Three-drug intra-arterial chemotherapy using simultaneous carboplatin, topotecan and melphalan for intraocular retinoblastoma: preliminary results. $\mathrm{Br}$ J Ophthalmol 2012;96:1300-1303.

13 Schaiquevich P, Carcaboso AM, Buitrago E, Taich P, Opezzo J, Bramuglia G, Chantada GL: Ocular pharmacology of topotecan and its activity in retinoblastoma. Retina 2014;34:1719-1727.

14 Garst J: Topotecan: An evolving option in the treatment of relapsed small cell lung cancer. Ther Clin Risk Manag 2007;3:1087-1095.

15 Hartwell D, Jones J, Loveman E, Harris P, Clegg A, Bird A: Topotecan for relapsed small cell lung cancer: a systematic review and economic evaluation. Cancer Treat Rev 2011;37:242-249.

16 Loveman E, Jones J, Hartwell D, Bird A, Harris P, Welch K, Clegg A: The clinical effectiveness and costeffectiveness of topotecan for small cell lung cancer: a systematic review and economic evaluation. Health Technol Assess 2010;14:1-204.

17 Pirker R, Berzinec P, Brincat S, Kasan P, Ostoros G, Pesek M, Plate S, Purkalne G, Rooneem R, Skrickova J, Stanculeanu D, Timcheva C, Tzekova V, Zakotnik B, Zielinski CC, Zwitter M: Therapy of small cell lung cancer with emphasis on oral topotecan. Lung Cancer 2010;70:7-13. 


\section{Cellular Physiology Cell Physiol Biochem 2015;37:1607-1618 \begin{tabular}{l|l|l} 
DOI: 10.1159/000438527 & C 2015 S. Karger AG, Basel
\end{tabular} and Biochemistry Published online: November 05, $2015 \quad$ www.karger.com/cpb \\ Bissinger et al.: Topotecan-Induced Eryptosis}

18 Riemsma R, Simons JP, Bashir Z, Gooch CL, Kleijnen J: Systematic Review of topotecan (Hycamtin) in relapsed small cell lung cancer. BMC Cancer 2010;10:436.

19 Kasow KA, Stewart CF, Barfield RC, Wright NL, Li C, Srivastava DK, Leung W, Horwitz EM, Bowman LC, Handgretinger R, Hale GA: A phase I/II study of CY and topotecan in patients with high-risk malignancies undergoing autologous hematopoietic cell transplantation: the St Jude long-term follow-up. Bone Marrow Transplant 2012;47:1448-1454.

20 Wiernik PH, Li H, Weller E, Hochster HS, Horning SJ, Nazeer T, Gordon LI, Habermann TM, Minniti CJ Jr, Shapiro GR, Cassileth PA: Activity of topotecan 21-day infusion in patients with previously treated large cell lymphoma: long-term follow-up of an Eastern Cooperative Oncology Group study (E5493). Leuk Lymphoma 2012;53:1137-1142.

21 Daladimos T, Theotikos E, Athanasopoulos A, Tsakonas G, Karabelis A, Mylonakis N, Kosmas C: Second high-dose chemotherapy intensification followed by hematopoietic stem cell transplantation applying a novel high-dose topotecan-based regimen in an adult Wilms' tumor patient: case report. Anticancer Drugs 2011;22:111-114.

22 Cui J, Li C, Wang C, Li Y, Zhang L, Zhang L, Xiu X, Li Y, Wei N: Nigericin-mediated liposome loading of topotecan: is nigericin a potential drug release regulator? Int J Pharm 2010;399:31-36.

23 Morgan RJ, Synold T, Mamelak A, Lim D, Al-Kadhimi Z, Twardowski P, Leong L, Chow W, Margolin K, Shibata S, Somlo G, Yen Y, Frankel P, Doroshow JH: Plasma and cerebrospinal fluid pharmacokinetics of topotecan in a phase I trial of topotecan, tamoxifen, and carboplatin, in the treatment of recurrent or refractory brain or spinal cord tumors. Cancer Chemother Pharmacol 2010;66:927-933.

24 Eckardt JR, von Pawel J, Pujol JL, Papai Z, Quoix E, Ardizzoni A, Poulin R, Preston AJ, Dane G, Ross G: Phase III study of oral compared with intravenous topotecan as second-line therapy in small-cell lung cancer. J Clin Oncol 2007;25:2086-2092.

25 Hormann V, Kumi-Diaka J, Durity M, Rathinavelu A: Anticancer activities of genistein-topotecan combination in prostate cancer cells. J Cell Mol Med 2012;16:2631-2636.

26 Khalife R, Stephany el H, Tarras O, Hodroj MH, Rizk S: Antiproliferative and proapoptotic effects of topotecan in combination with thymoquinone on acute myelogenous leukemia. Clin Lymphoma Myeloma Leuk 2014;14 Suppl:S46-55.

27 Kim MK, James J, Annunziata CM: Topotecan synergizes with CHEK1 (CHK1) inhibitor to induce apoptosis in ovarian cancer cells. BMC Cancer 2015;15:196.

28 Gantar M, Dhandayuthapani S, Rathinavelu A: Phycocyanin induces apoptosis and enhances the effect of topotecan on prostate cell line LNCaP. J Med Food 2012;15:1091-1095.

29 Schumacher M, Hautzinger A, Rossmann A, Holzhauser S, Popovic D, Hertrampf A, Kuntz S, Boll M, Wenzel U: Chrysin blocks topotecan-induced apoptosis in Caco-2 cells in spite of inhibition of ABC-transporters. Biochem Pharmacol 2010;80:471-479.

30 Tsang PS, Cheuk AT, Chen QR, Song YK, Badgett TC, Wei JS, Khan J: Synthetic lethal screen identifies NFkappaB as a target for combination therapy with topotecan for patients with neuroblastoma. BMC Cancer 2012;12:101.

31 Wang Y, Peng RQ, Li DD, Ding Y, Wu XQ Zeng YX, Zhu XF, Zhang XS: Chloroquine enhances the cytotoxicity of topotecan by inhibiting autophagy in lung cancer cells. Chin J Cancer 2011;30:690-700.

32 Zhang M, Shan BE, Yuan NF, Liu W: Effect of topotecan on retinocytoma cell apoptosis and expression of Livin and PTEN. Chin Med J (Engl) 2013;126:340-344.

33 Zhang Y, Chen X, Ren P, Su Z, Cao H, Zhou J, Zou X, Fu S, Lin S, Fan J, Yang B, Sun X, Zhou Y, Chen Y, Yang L, $\mathrm{Wu}$ J: Synergistic effect of combination topotecan and chronomodulated radiation therapy on xenografted human nasopharyngeal carcinoma. Int J Radiat Oncol Biol Phys 2013;87:356-362.

34 Dudas J, Bocsi J, Fullar A, Baghy K, Fule T, Kudaibergenova S, Kovalszky I: Heparin and liver heparan sulfate can rescue hepatoma cells from topotecan action. Biomed Res Int 2014;2014:765794.

35 Sato A, Asano T, Horiguchi A, Ito K, Sumitomo M, Asano T: Antitumor effect of suberoylanilide hydroxamic acid and topotecan in renal cancer cells. Oncol Res 2011;19:217-223.

36 Tsunetoh S, Terai Y, Sasaki H, Tanabe A, Tanaka Y, Sekijima T, Fujioka S, Kawaguchi H, Kanemura M, Yamashita Y, Ohmichi M: Topotecan as a molecular targeting agent which blocks the Akt and VEGF cascade in platinum-resistant ovarian cancers. Cancer Biol Ther 2010;10:1137-1146.

37 Zhang FL, Wang P, Liu YH, Liu LB, Liu XB, Li Z, Xue YX: Topoisomerase I inhibitors, shikonin and topotecan, inhibit growth and induce apoptosis of glioma cells and glioma stem cells. PLoS One 2013;8:e81815. 


\section{Cellular Physiology Cell Physiol Biochem 2015;37:1607-1618

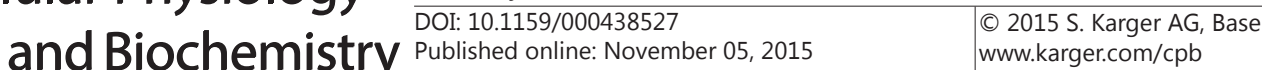

38 Sottile F, Gnemmi I, Cantilena S, D'Acunto WC, Sala A: A chemical screen identifies the chemotherapeutic drug topotecan as a specific inhibitor of the B-MYB/MYCN axis in neuroblastoma. Oncotarget 2012;3:535545.

39 Lang PA, Kaiser S, Myssina S, Wieder T, Lang F, Huber SM: Role of Ca2+-activated K+ channels in human erythrocyte apoptosis. Am J Physiol Cell Physiol 2003;285:C1553-C1560.

40 Lang E, Qadri SM, Lang F: Killing me softly - suicidal erythrocyte death. Int J Biochem Cell Biol 2012;44:1236-1243.

41 Abed M, Towhid ST, Mia S, Pakladok T, Alesutan I, Borst O, Gawaz M, Gulbins E, Lang F: Sphingomyelinaseinduced adhesion of eryptotic erythrocytes to endothelial cells. Am J Physiol Cell Physiol 2012;303:C991999.

42 Lau IP, Chen H, Wang J, Ong HC, Leung KC, Ho HP, Kong SK: In vitro effect of CTAB- and PEG-coated gold nanorods on the induction of eryptosis/erythroptosis in human erythrocytes. Nanotoxicology 2012;6:847856.

43 Maellaro E, Leoncini S, Moretti D, Del Bello B, Tanganelli I, De Felice C, Ciccoli L: Erythrocyte caspase-3 activation and oxidative imbalance in erythrocytes and in plasma of type 2 diabetic patients. Acta Diabetol 2013;50:489-495.

44 Kucherenko Y, Zelenak C, Eberhard M, Qadri SM, Lang F: Effect of casein kinase 1alpha activator pyrvinium pamoate on erythrocyte ion channels. Cell Physiol Biochem 2012;30:407-417.

45 Zelenak C, Eberhard M, Jilani K, Qadri SM, Macek B, Lang F: Protein kinase CK1alpha regulates erythrocyte survival. Cell Physiol Biochem 2012;29:171-180.

46 Bhavsar SK, Gu S, Bobbala D, Lang F: Janus kinase 3 is expressed in erythrocytes, phosphorylated upon energy depletion and involved in the regulation of suicidal erythrocyte death. Cell Physiol Biochem 2011;27:547-556.

47 Klarl BA, Lang PA, Kempe DS, Niemoeller OM, Akel A, Sobiesiak M, Eisele K, Podolski M, Huber SM, Wieder T, Lang F: Protein kinase C mediates erythrocyte "programmed cell death" following glucose depletion. Am J Physiol Cell Physiol 2006;290:C244-253.

48 Gatidis S, Zelenak C, Fajol A, Lang E, Jilani K, Michael D, Qadri SM, Lang F: p38 MAPK activation and function following osmotic shock of erythrocytes. Cell Physiol Biochem 2011;28:1279-1286.

49 Zelenak C, Foller M, Velic A, Krug K, Qadri SM, Viollet B, Lang F, Macek B: Proteome analysis of erythrocytes lacking AMP-activated protein kinase reveals a role of PAK2 kinase in eryptosis. J Proteome Res 2011;10:1690-1697.

50 Foller M, Sopjani M, Koka S, Gu S, Mahmud H, Wang K, Floride E, Schleicher E, Schulz E, Munzel T, Lang F: Regulation of erythrocyte survival by AMP-activated protein kinase. FASEB J 2009;23:1072-1080.

51 Foller M, Feil S, Ghoreschi K, Koka S, Gerling A, Thunemann M, Hofmann F, Schuler B, Vogel J, Pichler B, Kasinathan RS, Nicolay JP, Huber SM, Lang F, Feil R: Anemia and splenomegaly in cGKI-deficient mice. Proc Natl Acad Sci U S A 2008;105:6771-6776.

52 Lupescu A, Shaik N, Jilani K, Zelenak C, Lang E, Pasham V, Zbidah M, Plate A, Bitzer M, Foller M, Qadri SM, Lang F: Enhanced erythrocyte membrane exposure of phosphatidylserine following sorafenib treatment: an in vivo and in vitro study. Cell Physiol Biochem 2012;30:876-888.

53 Shaik N, Lupescu A, Lang F: Sunitinib-sensitive suicidal erythrocyte death. Cell Physiol Biochem 2012;30:512-522.

54 Jilani K, Qadri SM, Lang F: Geldanamycin-induced phosphatidylserine translocation in the erythrocyte membrane. Cell Physiol Biochem 2013;32:1600-1609.

55 Vota DM, Maltaneri RE, Wenker SD, Nesse AB, Vittori DC: Differential erythropoietin action upon cells induced to eryptosis by different agents. Cell Biochem Biophys 2013;65:145-157.

56 Zappulla D: Environmental stress, erythrocyte dysfunctions, inflammation, and the metabolic syndrome: adaptations to CO2 increases? J Cardiometab Syndr 2008;3:30-34.

57 Zbidah M, Lupescu A, Jilani K, Lang F: Stimulation of suicidal erythrocyte death by fumagillin. Basic Clin Pharmacol Toxicol 2013;112:346-351.

58 Abed M, Herrmann T, Alzoubi K, Pakladok T, Lang F: Tannic Acid induced suicidal erythrocyte death. Cell Physiol Biochem 2013;32:1106-1116.

59 Ahmed MS, Langer H, Abed M, Voelkl J, Lang F: The uremic toxin acrolein promotes suicidal erythrocyte death. Kidney Blood Press Res 2013;37:158-167. 


\section{Cellular Physiology Cell Physiol Biochem 2015;37:1607-1618

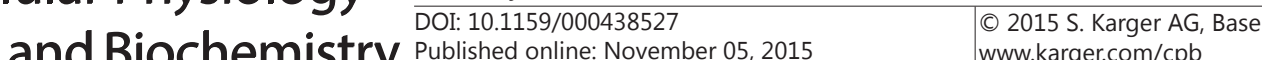

60 Ghashghaeinia M, Cluitmans JC, Toulany M, Saki M, Koberle M, Lang E, Dreischer P, Biedermann T, Duszenko M, Lang F, Bosman GJ, Wieder T: Age Sensitivity of NFkappaB Abundance and Programmed Cell Death in Erythrocytes Induced by NFkappaB Inhibitors. Cell Physiol Biochem 2013;32:801-813.

61 Alzoubi K, Honisch S, Abed M, Lang F: Triggering of Suicidal Erythrocyte Death by Penta-O-galloyl-beta-dglucose. Toxins (Basel) 2014;6:54-65.

62 Jilani K, Lang F: Carmustine-induced phosphatidylserine translocation in the erythrocyte membrane. Toxins (Basel) 2013;5:703-716.

63 Jilani K, Enkel S, Bissinger R, Almilaji A, Abed M, Lang F: Fluoxetine induced suicidal erythrocyte death. Toxins (Basel) 2013;5:1230-1243.

64 Lupescu A, Bissinger R, Jilani K, Lang F: Triggering of suicidal erythrocyte death by celecoxib. Toxins (Basel) 2013;5:1543-1554.

65 Lupescu A, Jilani K, Zbidah M, Lang F: Patulin-induced suicidal erythrocyte death. Cell Physiol Biochem 2013;32:291-299.

66 Abed M, Zoubi KA, Theurer M, Lang F: Effect of dermaseptin on erythrocytes. Basic Clin Pharmacol Toxicol 2013;113:347-352.

67 Arnold M, Lang E, Modicano P, Bissinger R, Faggio C, Abed M, Lang F: Effect of nitazoxanide on erythrocytes. Basic Clin Pharmacol Toxicol 2014;114:421-426.

68 Oswald G, Alzoubi K, Abed M, Lang F: Stimulation of suicidal erythrocyte death by ribavirin. Basic Clin Pharmacol Toxicol 2014;114:311-317.

69 Bissinger R, Malik A, Jilani K, Lang F: Triggering of Erythrocyte Cell Membrane Scrambling by Salinomycin. Basic Clin Pharmacol Toxicol 2014;10.1111/bcpt.12250

70 Abed M, Feger M, Alzoubi K, Pakladok T, Frauenfeld L, Geiger C, Towhid ST, Lang F: Sensitization of erythrocytes to suicidal erythrocyte death following water deprivation. Kidney Blood Press Res 2013;37:567-578.

71 Alzoubi K, Calabròa S, Bissinger R, Abed M, Faggio C, Lang F: Stimulation of Suicidal Erythrocyte Death by Artesunate. Cell Physiol Biochem 2014;34:2232-2244.

72 Arnold M, Bissinger R, Lang F: Mitoxantrone-induced suicidal erythrocyte death. Cell Physiol Biochem 2014;34:1756-1767.

73 Bissinger R, Fischer S, Jilani K, Lang F: Stimulation of Erythrocyte Death by Phloretin. Cell Physiol Biochem 2014;34:2256-2265.

74 Bissinger R, Lupescu A, Zelenak C, Jilani K, Lang F: Stimulation of eryptosis by cryptotanshinone. Cell Physiol Biochem 2014;34:432-442.

75 Bissinger R, Modicano P, Frauenfeld L, Lang E, Jacobi J, Faggio C, Lang F: Estramustine-induced suicidal erythrocyte death. Cell Physiol Biochem 2013;32:1426-1436.

76 Jacobi J, Lang E, Bissinger R, Frauenfeld L, Modicano P, Faggio C, Abed M, Lang F: Stimulation of erythrocyte cell membrane scrambling by mitotane. Cell Physiol Biochem 2014;33:1516-1526.

77 Lupescu A, Bissinger R, Herrmann T, Oswald G, Jilani K, Lang F: Induction of suicidal erythrocyte death by novobiocin. Cell Physiol Biochem 2014;33:670-680.

78 Lupescu A, Bissinger R, Warsi J, Jilani K, Lang F: Stimulation of erythrocyte cell membrane scrambling by gedunin. Cell Physiol Biochem 2014;33:1838-1848.

79 Malik A, Bissinger R, Calabro S, Faggio C, Jilani K, Lang F: Aristolochic Acid Induced Suicidal Erythrocyte Death. Kidney Blood Press Res 2014;39:408-419.

80 Tesoriere L, Attanzio A, Allegra M, Cilla A, Gentile C, Livrea MA: Oxysterol mixture in hypercholesterolemiarelevant proportion causes oxidative stress-dependent eryptosis. Cell Physiol Biochem 2014;34:10751089.

81 Voelkl J, Alzoubi K, Mamar AK, Ahmed MS, Abed M, Lang F: Stimulation of suicidal erythrocyte death by increased extracellular phosphate concentrations. Kidney Blood Press Res 2013;38:42-51.

82 Zhang R, Xiang Y, Ran Q, Deng X, Xiao Y, Xiang L, Li Z: Involvement of calcium, reactive oxygen species, and ATP in hexavalent chromium-induced damage in red blood cells. Cell Physiol Biochem 2014;34:1780-1791.

83 Alzoubi K, Calabro S, Egler J, Faggio C, Lang F: Triggering of programmed erythrocyte death by alantolactone. Toxins (Basel) 2014;6:3596-3612.

84 Faggio C, Alzoubi K, Calabro S, Lang F: Stimulation of suicidal erythrocyte death by PRIMA-1. Cell Physiol Biochem 2015;35:529-540. 


\section{Cellular Physiology Cell Physiol Biochem 2015;37:1607-1618 \begin{tabular}{l|l|l}
\hline DOI: 10.1159/000438527 & C 2015 S. Karger AG, Basel
\end{tabular} and Biochemistry Published online: November 05, $2015 \quad$ www.karger.com/cpb \\ Bissinger et al.: Topotecan-Induced Eryptosis}

85 Buitrago E, Hocht C, Chantada G, Fandino A, Navo E, Abramson DH, Schaiquevich P, Bramuglia GF: Pharmacokinetic analysis of topotecan after intra-vitreal injection. Implications for retinoblastoma treatment. Exp Eye Res 2010;91:9-14.

86 Abed M, Artunc F, Alzoubi K, Honisch S, Baumann D, Foller M, Lang F: Suicidal erythrocyte death in endstage renal disease. J Mol Med (Berl) 2014;92:871-879.

87 Calderon-Salinas JV, Munoz-Reyes EG, Guerrero-Romero JF, Rodriguez-Moran M, Bracho-Riquelme RL, Carrera-Gracia MA, Quintanar-Escorza MA: Eryptosis and oxidative damage in type 2 diabetic mellitus patients with chronic kidney disease. Mol Cell Biochem 2011;357:171-179.

88 Polak-Jonkisz D, Purzyc L: Ca(2+) influx versus efflux during eryptosis in uremic erythrocytes. Blood Purif 2012;34:209-210; author reply 210.

89 Lang PA, Beringer O, Nicolay JP, Amon O, Kempe DS, Hermle T, Attanasio P, Akel A, Schafer R, Friedrich B, Risler T, Baur M, Olbricht CJ, Zimmerhackl LB, Zipfel PF, Wieder T, Lang F: Suicidal death of erythrocytes in recurrent hemolytic uremic syndrome. J Mol Med (Berl) 2006;84:378-388.

90 Nicolay JP, Schneider J, Niemoeller OM, Artunc F, Portero-Otin M, Haik G, Jr., Thornalley PJ, Schleicher E, Wieder T, Lang F: Stimulation of suicidal erythrocyte death by methylglyoxal. Cell Physiol Biochem 2006;18:223-232.

91 Lang E, Gatidis S, Freise NF, Bock H, Kubitz R, Lauermann C, Orth HM, Klindt C, Schuier M, Keitel V, Reich M, Liu G, Schmidt S, Xu HC, Qadri SM, Herebian D, Pandyra AA, Mayatepek E, Gulbins E, Lang F, Haussinger D, Lang KS, Foller M, Lang PA: Conjugated bilirubin triggers anemia by inducing erythrocyte death. Hepatology 2015;61:275-284.

92 Qadri SM, Mahmud H, Lang E, Gu S, Bobbala D, Zelenak C, Jilani K, Siegfried A, Foller M, Lang F: Enhanced suicidal erythrocyte death in mice carrying a loss-of-function mutation of the adenomatous polyposis coli gene. J Cell Mol Med 2012;16:1085-1093.

93 Kempe DS, Akel A, Lang PA, Hermle T, Biswas R, Muresanu J, Friedrich B, Dreischer P, Wolz C, Schumacher U, Peschel A, Gotz F, Doring G, Wieder T, Gulbins E, Lang F: Suicidal erythrocyte death in sepsis. J Mol Med (Berl) 2007;85:273-281.

94 Lang PA, Schenck M, Nicolay JP, Becker JU, Kempe DS, Lupescu A, Koka S, Eisele K, Klarl BA, Rubben H, Schmid KW, Mann K, Hildenbrand S, Hefter H, Huber SM, Wieder T, Erhardt A, Haussinger D, Gulbins E, Lang F: Liver cell death and anemia in Wilson disease involve acid sphingomyelinase and ceramide. Nat Med 2007;13:164-170.

95 Harrison HE, Bunting H, Ordway NK, Albrink WS: The Pathogenesis of the Renal Injury Produced in the Dog by Hemoglobin or Methemoglobin. J Exp Med 1947;86:339-356.

96 Foller M, Bobbala D, Koka S, Huber SM, Gulbins E, Lang F: Suicide for survival--death of infected erythrocytes as a host mechanism to survive malaria. Cell Physiol Biochem 2009;24:133-140.

97 Kirk K: Membrane transport in the malaria-infected erythrocyte. Physiol Rev 2001;81:495-537.

98 Ayi K, Giribaldi G, Skorokhod A, Schwarzer E, Prendergast PT, Arese P: 16alpha-bromoepiandrosterone, an antimalarial analogue of the hormone dehydroepiandrosterone, enhances phagocytosis of ring stage parasitized erythrocytes: a novel mechanism for antimalarial activity. Antimicrob Agents Chemother 2002;46:3180-3184.

99 Ayi K, Turrini F, Piga A, Arese P: Enhanced phagocytosis of ring-parasitized mutant erythrocytes: a common mechanism that may explain protection against falciparum malaria in sickle trait and beta-thalassemia trait. Blood 2004;104:3364-3371.

100 Cappadoro M, Giribaldi G, O'Brien E, Turrini F, Mannu F, Ulliers D, Simula G, Luzzatto L, Arese P: Early phagocytosis of glucose-6-phosphate dehydrogenase (G6PD)-deficient erythrocytes parasitized by Plasmodium falciparum may explain malaria protection in G6PD deficiency. Blood 1998;92:2527-2534.

101 Koka S, Huber SM, Boini KM, Lang C, Foller M, Lang F: Lead decreases parasitemia and enhances survival of Plasmodium berghei-infected mice. Biochem Biophys Res Commun 2007;363:484-489.

102 Koka S, Lang C, Niemoeller OM, Boini KM, Nicolay JP, Huber SM, Lang F: Influence of NO synthase inhibitor L-NAME on parasitemia and survival of Plasmodium berghei infected mice. Cell Physiol Biochem 2008;21:481-488.

103 Borst O, Abed M, Alesutan I, Towhid ST, Qadri SM, Foller M, Gawaz M, Lang F: Dynamic adhesion of eryptotic erythrocytes to endothelial cells via CXCL16/SR-PSOX. Am J Physiol Cell Physiol 2012;302:C644-C651. 


\section{Cellular Physiology Cell Physiol Biochem 2015;37:1607-1618

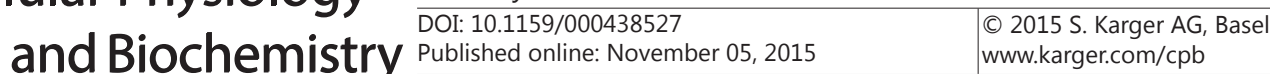 \\ Bissinger et al.: Topotecan-Induced Eryptosis}

104 Andrews DA, Low PS: Role of red blood cells in thrombosis. Curr Opin Hematol 1999;6:76-82.

105 Chung SM, Bae ON, Lim KM, Noh JY, Lee MY, Jung YS, Chung JH: Lysophosphatidic acid induces thrombogenic activity through phosphatidylserine exposure and procoagulant microvesicle generation in human erythrocytes. Arterioscler Thromb Vasc Biol 2007;27:414-421.

106 Zwaal RF, Comfurius P, Bevers EM: Surface exposure of phosphatidylserine in pathological cells. Cell Mol Life Sci 2005;62:971-988.

107 Closse C, Dachary-Prigent J, Boisseau MR: Phosphatidylserine-related adhesion of human erythrocytes to vascular endothelium. Br J Haematol 1999;107:300-302.

108 Gallagher PG, Chang SH, Rettig MP, Neely JE, Hillery CA, Smith BD, Low PS: Altered erythrocyte endothelial adherence and membrane phospholipid asymmetry in hereditary hydrocytosis. Blood 2003;101:46254627.

109 Pandolfi A, Di Pietro N, Sirolli V, Giardinelli A, Di Silvestre S, Amoroso L, Di Tomo P, Capani F, Consoli A, Bonomini M: Mechanisms of uremic erythrocyte-induced adhesion of human monocytes to cultured endothelial cells. J Cell Physiol 2007;213:699-709.

110 Wood BL, Gibson DF, Tait JF: Increased erythrocyte phosphatidylserine exposure in sickle cell disease: flow-cytometric measurement and clinical associations. Blood 1996;88:1873-1880. 